\title{
IMPACT OF SPATIAL PLANNING ON THE PRE- INVESTMENT PHASE OF THE DEVELOPMENT PROCESS IN THE RESIDENTIAL CONSTRUCTION FIELD
}

\begin{abstract}
J. SOBIERAJ ${ }^{1}$
Insufficient due planning policy in Poland is subject to widespread and justified criticism. This applies to all levels of spatial management. Legal instruments governing spatial planning in Poland are passive - setting out only the legal framework corresponding to a particular area. They regulate what might be developed within its boundaries, however, they do not specify how it is to be accomplished. Therefore, there is a need to develop an integrated spatial development planning, in which also investors and/or stakeholders would be involved. Apart from answering to the question of what is going to be developed, it will also provide a very comprehensive and flexible implementation strategy having regard to different timelines and local amenities (facilities). This paper also brings an example showing how the spatial planning strategy was conducted for the development of the "Fort Bema" housing estates in the Warsaw district of Bemowo. It highlights the relevance of the planning phase for the subsequent in-use (operating) phase.
\end{abstract}

Keywords: spatial development planning, pre-investment phase, development processes, Fort Bema Park

\section{INTRODUCTION}

Most project management methodologies focus on the implementation (realization) phase, according to the author, while omitting important stages of the pre-investment phase which is pivotal for designing a successful project in the housing construction i.e. elaboration and adoption

\footnotetext{
${ }^{1}$ PhD., Eng., Warsaw University of Technology, Faculty of Civil Engineering, Al. Armii Ludowej 16, 00-637 Warsaw, Poland, President of Korporacja Radex S.A., e-mail: jsobieraj@korporacjaradex.pl
} 
of the spatial development conditions and directions study and the local spatial development plan. More attention should be paid to the role of the planning phase in the project management, especially taking into account the fact that realization of this phase is relatively less expensive when compared with other phases. With good preparation and planning of a project, one can avoid costly mistakes in the implementation phase and unnecessary problems. In the initial phase it is actually possible to abandon a project without incurring unnecessary further costs (e.g. a purchase of land plot etc.) if its implementation is vitiated by risks that are too high or when it exceeds investor's financial capacity or simply when it is not profitable (economically substantiated).

\section{Spatial Planning System}

Spatial planning system in Poland includes, inter alia, the following planning acts [1]:

a. The concept of country's spatial management and planning - which is drawn up by the relevant minister of regional development, including the objectives set out in government policy documents and incorporating the rule of country's sustainable development (based on natural, cultural, social and economic conditions),

b. The provincial spatial development plan, of which the urban and spatial development plan of the provincial functional center area constitutes an integral part - which may also include the areas lying beyond the limits of the center zone,

c. The municipal study of conditions and directions of spatial development, which should be drawn up for the entire municipality area within its administrative borders - and which can be partially modified (for different parts of a municipality/commune),

d. Local urban and spatial development plans, which are drawn up for an entire municipality, or for its individual parts, and which can be globally or partially modified.

All of these types of acts of spatial planning are of passive character. They define the rules and conditions of urban and spatial planning as well as the management of lands (activities and elaborations regarding spatial planning that are required by law are given in table no. 1). They do not specify, however, the actions that should be conducted in order to achieve the planned status of their development. For this reason, they are not sufficient to implement an active spatial development policy.

There is, therefore, a need to develop another type of a plan that will serve for creation of the desired spatial development e.g. a "logistics valley", an "aviation valley" or housing estates as a 
whole and/or for their individual parts. The Integrated Spatial Development Plan (ISDP) accommodates all the above-mentioned necessities - with the full awareness that this type of a plan does not have the legal basis and its adaptation with respect to the statutory plans and programs as well as its implementation (realization) will depend on the consequence of actions of investor's Executive Committee and on its acceptance by the municipalities/cities and provincial authorities.

Table 1. Activities of public administration entities in terms of urban and spatial planning

\begin{tabular}{|c|c|c|}
\hline $\begin{array}{l}\text { Decision-making } \\
\text { level }\end{array}$ & Activities & Elaborations and documents \\
\hline $\begin{array}{l}\text { Municipality: } \\
\text { municipal council, } \\
\text { head of a } \\
\text { commune/mayor/ } \\
\text { president of a city }\end{array}$ & $\begin{array}{l}\text { - } \quad \text { shaping and conducting } \\
\text { municipal spatial policy }\end{array}$ & $\begin{array}{l}\text { - the spatial development conditions and directions study } \\
\text { - local area spatial development plan } \\
\text { - analyses of changes in spatial planning of a } \\
\text { municipality/commune } \\
\text { - decision concerning the location of a public purpose } \\
\text { investment (outside closed areas) } \\
\text { - decision regarding planning permissions (outside } \\
\text { closed areas) }\end{array}$ \\
\hline $\begin{array}{l}\text { Poviat: } \\
\text { Poviat } \\
\text { governments } \\
\text { (Poviat autonomy) }\end{array}$ & & $\begin{array}{l}\text { - analyses and studies in relation to a specific } \\
\text { territorial competence or a specialised operational } \\
\text { responsibility }\end{array}$ \\
\hline $\begin{array}{l}\text { Voivoidship: } \\
\text { regional cuncil and } \\
\text { Voivodship } \\
\text { authorities }\end{array}$ & $\begin{array}{l}\text { - } \quad \text { shaping and conducting } \\
\text { provincial spatial policy }\end{array}$ & $\begin{array}{l}\text { - urban and spatial development plan for a voivoidship } \\
\text { - studies and analyses } \\
\text { - concepts and projections (referring to the areas and } \\
\text { problems of the urban and spatial planning of a } \\
\text { voivoidship) }\end{array}$ \\
\hline $\begin{array}{l}\text { Country: } \\
\text { The Council of } \\
\text { Ministers, } \\
\text { ministries and } \\
\text { central bodies of } \\
\text { government } \\
\text { administration }\end{array}$ & $\begin{array}{l}\text { - shaping and conducting } \\
\text { country's spatial policy, } \\
\text { foreign cooperation within } \\
\text { the scope of the urban and } \\
\text { spatial development }\end{array}$ & $\begin{array}{l}\text { - concepts of country's urban and spatial development } \\
\text { - analyses and studies } \\
\text { - concepts and projections (referring to the areas and } \\
\text { issues in terms of strategic programming and } \\
\text { forecasting the socio-economic development) } \\
\text { - programs of government activities } \\
\text { - periodic reports on the state of urban and spatial } \\
\text { development }\end{array}$ \\
\hline
\end{tabular}




\subsection{PROCEDURES OF DRAWING UP AND ENACTING OF LOCAL AREA SPATIAL DEVELOPMENT PLANS}

Polish system of urban and spatial development is based on the constitutional principle of decentralized public activities, which results in the transfer of the planning authority to the municipalities - or, put differently, the right of communal authorities to shape and conduct spatial policy within a municipality. Planning authority also includes the right to establish municipal planning studies [2].

Procedures for drawing up and adopting of the above-mentioned planning acts (which are designed to amend) are prepared at the municipal level and are considered to be similar at all decision-making levels.

Regulation of the Act on planning and spatial development provides a structured procedure for preparing and adopting of a local area development plan, which includes the following activities (Article 17, and the following of the Act 'PSDP'):

a. Adoption of a resolution on commencement of the realization of a local area plan (municipal council);

b. Public notice on commencement of the realization of a plan (head of a commune/mayor/president of a city), notifying about the possibility to submit applications referring to the future plan (specifying the place and time);

c. Head of a commune/mayor/president of a city shall draw up a local draft plan, considering all submitted applications;

d. Setting out the project with the entities indicated in the Act 'PSDP' and requesting for opinions of the authorities listed in the above-mentioned Act (i.e. head of a commune/mayor/president of a city);

e. Elaboration of the prediction of the impact of the local area plan arrangements on the environment, including preparation of the analysis regarding the effects of the implementation of the plan (head of commune/mayor/president of a city);

f. Fulfilling requirements for public disclosure of information regarding the plan (making the plan available to public view) upon its legislative changes arising from the arrangements and opinions, together with the prediction concerning its environmental impact, linked with the 
public discussion concerning the solutions adopted in the draft plan and the possibility for submitting comments to the draft plan;

g. Consideration of comments to the draft plan by a head of commune/mayor/president of a city, and introducing amendments to the draft plan, resulting from the considered comments and forwarding the draft plan to the municipal council, together with the list of comments that were rejected;

h. Adoption of the local area development plan, after preliminary determination of the integrity of arrangements included in the prevailing study (municipal council). The text part of the plan constitutes the Resolution and the graphic parts as well as the required settlements that are also incorporated into the Resolution;

i. Head of a commune/mayor/president of a city shall submit the resolution together with its attachments and the documentation regarding planned works in order to assess their compliance with the provisions of the legislation and for its publication in the Official Journal of the Province;

j. Evaluation of the local area development in terms of its timeliness in comparison with the urban and spatial development of the municipality (head of a commune/mayor/president of a city).

\subsection{CHARACTERISTICS OF THE INTEGRATED URBAN AND SPATIAL DEVELOPMENT}

\section{PLAN}

The Integrated Spatial Development Plan (ISDP) has the following characteristics:

a) it is a very comprehensive plan - which encompasses social, economic, environmental, cultural, spatial, communication, infrastructural and geodetic issues,

b) it is a directional plan - which encompasses different time horizons: strategic, operational and on-going (current),

c) it is a multi-scalar plan - which adjusts its scale and the level of detail of its findings to different time horizons (strategic, operational, and on-going),

d) it is a dynamic plan - that specifies actions of individual entities, and which is subject to periodic reviews and necessary modifications, 
e) it is an utilitarian plan - which serves as a basis for the conduct of preparatory actions (regulation of land ownership, design and development of infrastructure etc.) and an ongoing work (investment location),

f) it is a realistic plan - harmonizing the spatial development planning with financial capabilities and economic viabilities,

g) it is a flexible plan - which is written in such a manner so that it not causes a necessity for any changes of its constituent parts vis-à-vis the land area covered by the plan,

h) it has to be executed in accordance with the principles of the "good plan principles" elaborated by prof. T. Kotarbinski [3].

ISDP coordinates the laws of spatial planning, socio-economic development strategies and implementation programs. Currently, such a plan is being developed for the 'Dolina Logistyczna' (Logistics Valley) functional area 2020, with the 2050 perspective, covering several municipalities: the City of Gdynia, Kosakowo, Rumia, Wejherowo Reda, the City of Wejherowo, and other partners in the project (i.e.: Municipality of Cewice, Municipality of the City of Lębork, Municipality of Liniewo, Municipality of Luzino, Łęczyce, Szemud and Gniewino - which participate in the project as observers) [4].

\section{FLEXIBLE APPROACH TO THE AREA DEVELOPMENT PROCEDURE AND URBAN PLANNING ON THE EXAMPLE OF THE, „FORT BEMA” HOUSING ESTATES LOCATED IN THE BEMOWO DISTRICT IN WARSAW.}

Since the local area spatial development plan was formulated in a very general way (as long as it stays within the legal provisions) it became possible to apply the flexible approach to housing estates planning, without seeking each time the approval of its modifications. This would not be possible in the case of an adoption of the rigid planning provisions, which have so far been used in practice.

Negotiations with the monuments conservator to bring agreements on the draft plan were launched yet at the beginning of the planning process, and not at the end as it was commonly practiced, when the terms and conditions of a prepared draft plan were usually handed over to the monument conservator, what almost always led to lengthy disputes arising between different involved parties i.e. the author of the plan, the conservator and the municipality. The initiative to 
amend the existing functioning procedure was accepted enthusiastically by the conservator. The conservator issued relevant guidelines for the author of the plan, who then following several consultations and modifications, adopted them. For the first time in the history of Warsaw this simple innovation led to the avoidance of conflicts in the process of creation of the local area spatial development plan (for the historic site). The conservator did not raise any comments and objections to the proposed draft plan, or even for its formal settlement and adoption.

At the same time, for the first time in Warsaw's history, except the urban planner in the development of the plan also participated the representatives of future developers (including the president of the special-purpose company 'KR-WZLN' - the author of this paper). In this way, it was possible to delineate a graphic attachment to the plan, in which the development areas were marked (i.e. proposed segmentations).

Set out below are measurable benefits resulting from the application of flexible and innovative approaches to the proceeding and approving of the spatial development plan:

1. There were implemented the areas for pedestrian and motor traffic, what at the speed limit of $25 \mathrm{~km} / \mathrm{h}$ in the residential areas substantially improved safety in the vicinity of the housing estates;

2. In the forest park children's playgrounds were built, as well as volleyball pitches and the place for playing table tennis (after conversion of the forestry land into the forest park and the exclusion of 1 hectare of the forest from forestry production);

3. Gateways from the housing estates to the municipal landscape park were also built, and a two-hectare children's playground went into operation;

4. The road separating the Fort Bema Park from the housing estates was liquidated (and the residential area was planted with greenery);

5. The sewage systems inlets and networks running outside the boundaries of the land plot were launched (within the area of the park in the place of the liquidated road), and in exchange the municipal rainfall water collector was placed, connecting the nearby streets: Obrońców Tobruku Street and Księcia Boleslawa Street up to the Fort Bema moat, following prior cleaning in the sand traps and separators; 
6. The separator and the rainwater settling tank were constructed and situated between the discharge of water from the roofs of buildings, parking areas and the pavements and roads (with hard surface) leading to the Fort Bema moat;

7. By introducing improvements and innovations, at the moat of the Fort Bema Park the pure water appeared;

8. One of the gateways (at the site of the passageway at Obrońców Tobruku Street) was connected to the housing estates (i.e. at different location than it was originally planned);

9. Appropriate provisions regarding education services allowed for the interexchange of two kindergartens' locations between two different land plots (instead of the school which turned out to be unnecessary). A walk to other schools usually took from 5 to 7 minutes, counting form the border of the "Parkowo-Leśne" housing estates to the gateways in schools' fences);

10. A stand-alone parking lot was built - 22 meters from the land plot boundaries. Also, part of the parking places, which were required for the housing estates, was balanced. Extra car parks premises were built for visitors and to minimize the car traffic on narrow residential streets. WZL-4 agreed to create a reserve land for the additional two free standing car parks for 500 and 336 places;

11. It became possible to avoid crossing the tree (and therefore, its preservation) that was growing on the designed heating network route, and which was classified by dendrologists as a natural monument;

12. The proportion of biologically active substances of 60 percent (in the total land plot area) was stipulated in a flexible way, which made it possible to preserve the most precious greenery and creation of the 2 hectares forest park, places for recreation and walking, as well as the residential playgrounds for the youngest residents of the housing estates. The estates were designed either in the places with the least greenery or wherever it was intended for the felling (i.e. poplar, acacia). Also, between the housing estates and the streets of the Duke Boleslaus and the Duke Janusz a natural 12-meter "greenbelt" was preserved, providing additional protection against the effects of noise.

New innovative approach to the planning process was also unusual in that a competitive tendering was carried out before the urban planner had even commenced to draw up the plan. The architects were obliged to design the segmentation lines (divisions' lines) of the 12,6 hectares land 
plot - into smaller building plots amounting to ca. 9000-9700 square meters (the preliminary study of the housing market had indicated the optimal building plots' sizes which were ideal for the developers). For the purposes of the tendering the urban planner presented his initial concept of the roads and networks, for the location of the 2 hectares forest park and the greenery protection zone at the site of the Obrońców Tobruku Street and the Księcia Bolesława Street, as well as the guidelines for the monuments' conservator. In the course of the tendering competition, above and beyond the suggested land use and facilities' location on the plot, also individual facilities' absorbency had to be specified, as well as the general project's visualization. 25 project teams were invited to participate in the competitive tendering however, eventually only 17 took part in the tender. Additional solutions referring to the public land area (outside the local land plot) were incorporated into the design works. Also, different solutions were proposed (some potentially surprising), such as stand-alone, multi-level parking lot for the WZL company and for the visitors of the "ParkowoLeśne" housing estates and residential units situated in their immediate vicinity (those who had to cover from 40 up to 100 meters from the buildings to their vehicles). This allowed for an increase of the absorbency of the land plot and provided a sizeable area for future car parks, while retaining as much as 60 percent of the green area coverage (biologically active surface). On the basis of the above-described concept, the 4-storey roofed car park was built on the land plot pertaining, to WZL-4, as well as the reserves for the next two car parks were envisaged (in total for 836 places).

From the beginning of the planning process, project originators persuaded the Mayor of the municipality so that he went into the composition of the initiators' team. Contacts were established with the Councils of residents of the neighboring residential units (housing estates), and the pertinent dialogue was a matter of getting together and exchanging opinions regarding the investment project within the area of 148 hectares development project.

All difficult issues were discussed in the Municipal Office in the presence of the Mayor, lawyers and other stakeholders. Yet at the very beginning of the planning process a meeting was held, in which future investment activities concerning the main land plot and its surrounding areas were postulated. Several rounds of such meetings and similar ones were held in total. Proper communication with residents and their representatives prevented from experiencing any major problems during the planning process as well as in the realization phase of the entire project.

The authors of the plan, Warsaw City Hall Spatial Planning Director, experts, investors and residents were invited for the session of the municipal council, during which the resolution approving the draft plan had to be approved. In the course of the meeting council members and 
residents were asking questions, raising comments and after an exhaustive discussions and following pertinent explanations, each crucial point was put to the vote (was subject to approval). However, the consensus could not be reached in two different areas (with respect to two issues). At the request of the main project coordinator, project initiator and one of many stakeholders, an application was submitted to transfer the final consideration of the resolution on approval of the plan for the next session and the next meeting was actually convened in the Municipal Office, exclusively to discuss these two contentious issues. The meeting was to be held within three weeks of the last session date and two weeks before the next session. It allowed for clarifying several concerns and reaching an agreement on amendments to the draft plan, which author of the plan agreed to introduce after prior consultations with the Architectural Urban Commission of the Municipality of Warsaw Bemowo. At the next session the draft plan was adopted unanimously. Actually, no one has reported any protests or objections to the plan, which was carried out at all its stages in a highly flexible manner. This case was without precedent in the modern history of Warsaw.

To sum up, flexible and innovative approach in managing development processes yet in the planning stage caused that the spatial development plan was adopted and approved in an extremely short period of 11 months. Since then, 15 years have passed and no other occurrence of similar relevance was reported, as in the case of Warsaw (despite the law modifications that substantially relaxed planning procedures) [1]. As it turns out, current industry standards allow for approving of a plan (despite much easier procedures under the new legislation) within 3-4 years.

\section{INFLUENCE OF THE OPERATING PHASE ON THE PRE-INVESTMENT PHASE}

Most project management methodologies disregard also the operating phase and the in-use phase, which is very important from the target owner's viewpoint. The end-user in question must have access to professional management system with respect to facilities, buildings, housing estates (residential units), so as to maintain technical efficiency of the premises, buildings, infrastructure and their surroundings at a reasonable costs of day-to-day operations. These costs must be eligible to be incurred by residents/end-users and acceptable by them. The relative impact of different stages of the development process on investment and operating costs are showed on Figure 1. 


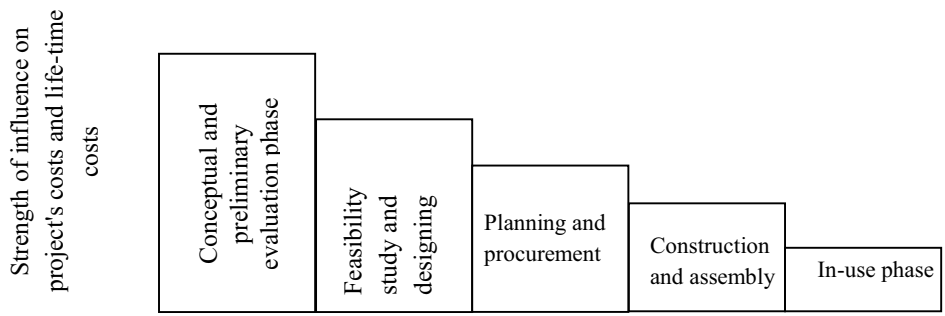

Figure 1. Relative impact of different project phases on investment expenditures and life-time costs.[5]

As it can be seen on the figure above any decisions taken in the in-use phase (operating phase), irrespective of the degree of accuracy, exert much less impact on the level of overall costs than the activities carried out in the initial phases of the project - and more specifically, in the spatial planning phase [6]. Naturally, it is easier to maintain a vast park adjacent to the housing estates, when the life-time costs are spread across a larger number of residential units (i.e. area's absorption depends on the number of storeys eligible to be constructed on a given land plot) and housing communities (housing estates), than to impose it on one housing community only. This synergy effect improves the overall housing conditions (green areas) in a given area and can be achieved only at the spatial planning phase level.

\section{CONCLUSIONS}

The lack of rational spatial policy in Poland is subject of widespread and legitimate criticism. This applies to all levels of spatial management. As shown in different reports of the scientific community, entrepreneurs and professional organizations, additionally supported by calls (postulates) of local self-government and community organizations, an unreasonable and irrational spatial management system results in measurable and rising economic/social losses [7]. This is particularly evident from the perspective of a practician of investment process management.

In the document entitled: "Theses concerning the improvement of the spatial legislation" elaborated by the Union of Polish Metropolises we read: "spatial chaos has negative economic and ecological effects. It causes an unreasonable increase in construction costs and subsistence costs of technical and social infrastructure (...)"[7]

In the resolution of the Fourth Congress of Polish Cities (2012) one reads the following postulates: "Law should allow for a rational spatial policy, simultaneously enacting legislative 
barriers and governance practices that restrict socially and economically harmful activities. (...) Improved law and regulations should facilitate investments by simplifying procedures and eliminating administrative barriers (...)"[8].

Moreover, as evidenced and proved earlier in the chapter 4, spatial planning has a significant influence on the in-use operating costs. This is a relatively least expensive phase (when compared to the implementation/realization phase - i.e. regarding the designing and constructing) and has a significant influence on the generation of costs in the subsequent phases. When planning and designing a building we need to think both of its handover and commissioning as well as of the costs which will be generated in the operating (in-use) phase.

Innovative and flexible approach to the investment process management in the Warsaw district of Bemowo (including in particular the procedures on adopting the local spatial development plans) contributed to a reduction of the cost of building infrastructure to an unprecedented level on the Warsaw market, of, 49 PLN per square metre of usable apartments area (PUM) and resulted in achieving a record-low costs of the design work (i.e. at the levels below 2 percent) with regard to the costs of construction and assembly work.

For comparison, the average infrastructure development cost in this location was 176 PLN per square metre, therefore all the developers and the initiators of the project achieved a very high added value as a result of this undertaking.

As pointed out earlier in this article, planning procedures are extensive and complex and it's not up to the local municipalities to show initiative in their adoption. Investors should pursue a proactive approach in shaping their plans, for example by creating Integrated Plans of Spatial Development, encompassing not only the planning framework and urban planning aspects but also economic and social ones. These plans are to include the objectives of all stakeholders in such a project and once the initial phase is complete they are also to involve successive stakeholders. Such plans must be flexible and respond to evolving dynamic market needs.

It is clear that the provisions of law must allow it as well as the social supervision of the pertinent procedures must be introduced so that investors need to strike a balance between their interests and the fulfilment of the social functions (i.e. providing land for the construction of nurseries, schools, pitches and sports halls, swimming pools, parks, recreational areas as well as for cinemas, clubs, cafes, cultural houses, hospitals, clinics, shops etc).

The whole world, Europe and each country on Earth is currently being transformed. In western countries, in China and India these changes occur very quickly, whereas in other parts of 
the world such progresses are slower and in some cases even very slow, e.g. Somalia in Africa or Tonga, Samoa in the South Pacific.

In certain developed countries there have been some stable and permanent migratory flows from rural to urban areas. This causes their rapid development which is, however, piecemeal and lacks of underlying planning and urban planning thoughts, or creates urban plans for relatively small areas (up to 20 hectares), thereby enclaves of prosperity are formed, lacking consistency with existing urban structure.

Therefore, every now and again (for example, every 10-20 years - which relies exclusively on the pace of cities' development) pertinent city strategic plans' inspections should be carried out, especially in relation to their substantial conformance with the real development progress. Appropriate corrections should be made for the adjustments and yet once again a renewed, comprehensive vision of city development should be created, and all this must be done, while again, fully involving the participation of residents and some of the brightest minds in the field of urban planning - the best national and world (the latter as in the case of metropolitan areas) urban planners.

Plans that are being worked out have to be so general and flexible (to the extent possible) as to allow for operating freely (see Annex 1).

An example of a new flexible and dynamic way of looking at the shaping of urban space is the described in this article way of preparing, commenting and adopting of the spatial plan which not only contributed to the creation of the most beautiful, safest and most environmentally friendly housing estates in the world but also led to a high level of profitability (high rate of return on invested capital) for the residents (see more details in J. Sobieraj's doctoral thesis).

We are now at a key moment in the sense that fourth industrial revolution is influencing almost every aspect of our lives (i.e. from economic and social perspective) and virtually affecting almost every sector, e.g. computer sciences, informatics, robotics, Internet etc., which will also have a huge impact on the development of cities and will also need to be of interest for urban planners and architects.

Today's world cries out for visionaries similar to those who designed such cities as Paris or Brasília as well as Málaga (its reconstruction took place at the turn of the 20th and 21st century).

Urban planning will be changed profoundly in the future due to such issues as:

- smart cities' infrastructure;

- pervasive electric vehicle (EV) charging stations like Tesla Superchargers; 
- Systems that enable inductive (wireless) battery charging while driving and allowing for capturing and collecting energy from vehicles' wheels;

- helicopters and unmanned aerial vehicles (drones);

- high speed vacuum tube train like Hyperloop;

- autonomous (self-driving) cars;

- elevated railway developments (Dubai);

- flying cars (such as Terrafugia TF-X);

- amphibious transport;

- innovative urban mass transport like PLP's CarTube which is the fusion of two modes of transport, automated electric cars and mass transit, into a single seamless urban mobility system;

- houses on water;

- barge style houseboats like those in Amsterdam;

- photovoltaic solar roads like those in France, USA and Netherlands.

\section{REFERENCES}

1. The Act of 27 March 2003 on spatial planning and development, published in the Journal of Laws on 10 May 2006 (Journal of Laws No. 80 item 721), entered into force on 11.07.2003 r. (with its subsequent amendments).

2. Available online: http://www.pts.org.pl/omdo/wp-content/uploads/2012/02/System-planowania-przestrzeni-wPolsce.pdf, Retrieved on 16.09.2015

3. T. Kotarbiński, "Efficiency and Error" (in polish), PZWS, Warsaw 1970, Poland, p.193

4. „The draft operational programme in managing economic development of the Dolina Logistyczna (Logistics valley) functional area 2020, with the 2050 perspective", Gdynia Development Agency, 2015, p.3

5. F.L. Harrison, „Advanced Project Management”, Gower, London 1985, UK, p.97

6. K. Najbar, A. Nalepa, „Participation of the property managers in development projects”, Research Bulletin n. 792, Cracow University of Economics, Poland, 2008., p.101

7. Kowalewski, Mordasewicz, Osiatyński, Regulski, Stępień, Śleszyński, „REPORT ON ECONOMIC LOSSES AND SOCIAL COSTS OF UNRESTRICTED URBANIZATION IN POLAND”, Warsaw, Poland, 29 October of 2013.

8. The resolution adopted by the participants of the Fourth Polish Urban Planning Congress in Lublin. The participants of the Congress were representatives from various circles (communities) e.g. local government officials and representatives of civic movements, investors, financiers and developers, urban planners and architects, September 2012, Poland 


\section{Annex 1}

\section{THE PRINCIPLES OF TADEUSZ KOTARBIŃSKI'S ACTION THEORY (GOOD PLAN OF ACTION)}

A good plan of action should be:

1) intentional and therefore determine the appropriate measures leading to the achievement of defined goals,

2) enforceable (feasible) i.e. that given the available resources and in certain conditions

gives a high possibility to reach the goal - this is a feature that corresponds with both its "reachability" and "limitations" (availability, feasibility), as the characteristics that make it possible to achieve the objectives set,

3) internally consistent, this means that it constitutes the whole in which individual goals are not in conflict with each other, and do not interfere with each other,

4) operational, i.e. clear, comprehensible and accurate, suitable for the implementation which is consistent with the use of resources and the chosen course of action,

5) flexible, (yielding, pliant), meaning that the plan itself provides for the possibility of a modification whenever it proves to be necessary in the event of a variation of conditions and means (as in the case of a change of law, regulations, weather, weather anomalies, project management etc.) - this is the very opposite of the inflexibility,

6) duly limited with respect to details; this is designed to leave more room to operate freely, otherwise an excessive detail may hinder the freedom of action; a detailed formal plan usually is unreal, and an excessively vague and generic plan ceases to be operationally feasible,

7) long term, of a forward-looking and forward-thinking nature within the limits of its ability to anticipate future problems,

8) on-time, which means that it should specify time limits for the completion of both the main goal and smaller intermediate goals (interim targets),

9) complete, taking into account the sum of activities performed (covering the whole operation),

10) rational and therefore thoroughly developed, taking into account all relevant considerations and indicating the causal relationships in view of a specific action to be taken. 


\section{TABLE OF FigurES:}

Table 1. Activities of public administration entities in terms of urban and spatial planning.

Tab. 1. Działalność podmiotów administracji publicznej w zakresie planowania przestrzennego i urbanistycznego.

Figure 1. Relative impact of different project phases on investment expenditures and life-time costs.

Fig. 1. Względny wpływ różnych faz projektu na wydatki inwestycyjne i koszty życia.

Annex 1. The principles of Tadeusz Kotarbiński's action theory (good plan of action).

Załącznik 1. Reguły ogólnej teorii sprawnego działania Tadeusza Kotarbińskiego. 


\section{WPLYW PLANOWANIA PRZESTRZENNEGO NA FAZE PRZED-INWESTYCYJNĄ PROCESU INWESTYCYJNEGO W BUDOWNICTWIE MIESZKANIOWYM}

Slowa kluczowe: planowanie przestrzenne, faza przed-inwestycyjna, procesy inwestycyjne, Fort Bema

\section{STRESZCZENIE:}

Brak racjonalnej polityki przestrzennej w Polsce jest przedmiotem powszechnej i uzasadnionej krytyki. Dotyczy to wszystkich poziomów zarządzania przestrzenią. Jak pokazują raporty środowisk naukowych, przedsiębiorców i organizacji zawodowych, poparte dodatkowo postulatami organizacji samorządowych i społecznych, nieracjonalny system zarządzania przestrzenią powoduje wymierne i rosnące straty społeczne oraz gospodarcze[7]. Jest to szczególnie widoczne z perspektywy praktyka zarządzania procesami inwestycyjnymi.

W dokumencie zatytułowanym: „Tezy do naprawy prawodawstwa przestrzennego” przygotowanym przez Unię Metropolii Polskich czytamy: „Chaos przestrzenny ma negatywne skutki ekonomiczne i ekologiczne. (...) Powoduje nieracjonalny wzrost kosztów budowy i utrzymania infrastruktury technicznej i spolecznej (...)”[7]

W rezolucji IV Kongresu Miast Polskich (2012) czytamy następujące postulaty : "Prawo winno umożliwić prowadzenie racjonalnej polityki przestrzennej, wprowadzając równocześnie bariery ustawowe i procedury nadzorcze, które ograniczaja dzialania szkodliwe spolecznie $i$ gospodarczo. (...) Zreformowane prawo winno ulatwiać inwestowanie, upraszczając procedury i eliminujac bariery administracyjne (...)”[8]

W swoim referacie przybliżyłem system planowania przestrzennego obowiązujący w Polsce wraz z obowiązującymi aktami prawnymi oraz wyszczególniłem zadania władz samorządowych i krajowych w zakresie planowania przestrzennego w podziale na poziom decyzyjny: gminy, powiatu, województwa i kraju. Na każdym z poziomów decyzyjnych są do opracowania różne dokumenty: od miejscowych planów zagospodarowania, aż po koncepcje przestrzennego zagospodarowania kraju.

Opisałem również procedurę sporządzania i uchwalania miejscowych planów zagospodarowania przestrzennego na poziomie gminy, które są zbliżone na wszystkich poziomach decyzyjnych. Procedury te są regulowane Ustawą o Planowaniu i Zagospodarowaniu Przestrzennym - głównie art. 17. Sporządzenie i uchwalenie miejscowego planu miejscowego jest bardzo czasochłonne i nawet pomimo uproszczenia procedur dalej w aglomeracji warszawskiej zajmuje 3-4 lata.

Akty prawne regulujące w Polsce planowanie przestrzenne mają charakter pasywny - określają jedynie ramy prawne co na danym obszarze może powstać, nie podają jednak w jaki sposób ma to być zrealizowane. Istnieje więc potrzeba opracowywania przez inwestorów czy interesariuszy zintegrowanych planów planowania przestrzennego, które będą odpowiadały nie tylko na pytanie co ma być wybudowane, ale też w kompleksowy i elastyczny sposób będą określały w różnych horyzontach czasowych strategię realizacji obiektów wraz z infrastrukturą na danym obszarze. W referacie podano pełną charakterystykę zintegrowanego planu rozwoju przestrzennego. Niniejszy referat przybliża również przykład w jaki sposób taka strategia planowania przestrzennego została zrealizowana na osiedlu „Fort Bema” na warszawskim Bemowie.

$\mathrm{Na}$ tym warszawskim osiedlu innowacyjne i elastyczne podejście do zarządzania procesem inwestycyjnym (w tym w szczególności do procedur uchwalania miejscowego planu zagospodarowania przestrzennego) spowodowało również obniżenie kosztów budowy infrastruktury do niespotykanego na rynku warszawskim poziomu 49 zł 
w odniesieniu do $1 \mathrm{~m} 2$ powierzchni użytkowej wybudowanych mieszkań i osiągnięcie niskiego wskaźnika, na poziomie poniżej 2 proc. - kosztów prac projektowych w odniesieniu do kosztów robót budowlano-montażowych. Dla porównania średnie koszty wybudowania infrastruktury technicznej w tej dzielnicy miasta wynosiły 176 zł. Uzyskano więc bardzo wysoką wartość dodaną dla wszystkich deweloperów i inicjatorów przedsięwzięcia. Uzyskanie takich efektów było możliwe tylko i wyłącznie przy ścisłej współpracy z architektami, urbanistami, deweloperami i władzami gminy i miasta, spółkami miejskim oraz konserwatorem zabytków. Dlatego właśnie do koordynowania tak dużych przedsięwzięć już na początku potrzebne jest opracowanie strategii, a w niej zintegrowanego planu rozwoju przestrzennego. Dzięki zaproszeniu wszystkich interesariuszy projektu już na etapie planowania uniknięto licznych sporów i poniesienia niepotrzebnych kosztów, które mogły by być wywołane zmienianiem kluczowych kwestii projektu już na etapie jego realizacji. Taka strategia prowadzenia przedsięwzięć inwestycyjnych spowodowała, że plan zagospodarowania przestrzennego został uchwalony i opublikowany w rekordowo krótkim okresie 11 miesięcy. Efektem tej strategii był powstanie jednego z najpiękniejszych, a na pewno najbardziej „zielonych” osiedli w Polsce z licznymi placami zabaw, obiektami sportowymi, parkami, zabytkowym fortem i fosą. Ponadto ruch samochodowy na osiedlu został przeniesiony na jego obrzeża, a mieszkańcom został udostępniony dodatkowo garaż wolnostojący.

Ponadto w rozdziale 4 niniejszego referatu pokazałem istotny wpływ jaki ma planowanie przestrzenne na koszty eksploatacji i użytkowania obiektu. Jest to faza stosunkowo najmniej kosztowna (w porównaniu do fazy realizacji projektowania i budowania), a ma istotny wpływ na generację kosztów w fazach następnych. Planując i projektując budynek musimy myśleć zarówno o jego odbiorze do użytkowania jak i o kosztach które będzie generował w fazie eksploatacji.

Jak wykazałem w referacie procedury planistyczne są rozległe i to nie samorządy gminne muszą się wykazywać inicjatywą $\mathrm{w}$ ich uchwalaniu. To inwestorzy powinny przyjąć aktywną postawę w kształtowaniu planów choćby przez tworzenie Zintegrowanych Planów Rozwoju Przestrzennego obejmujących nie tylko zagadnienia planistyczne i urbanistyczne ale także ekonomiczne i społeczne. Plany te powinny obejmować cele wszystkich interesariuszy takiego przedsięwzięcia i zakładać po początkowej fazie rozwoju przedsięwzięcia (w szczególności po wybudowaniu niezbędnej infrastruktury jak np. dojazdy, sieci) przyciągnięcie kolejnych. Muszą się one cechować przez to dużą elastycznością i odpowiadać na dynamicznie zmieniające się potrzeby rynku. 